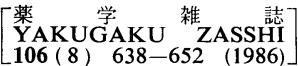

\title{
発癌性複素芳香族アミンによる化学発癌初期過程の研究から制癌剤分子設計へ
}

\author{
橋本祐一 \\ 東京大学薬学部, $\bar{\top} 113$, 文京区本郷 7-3-1
}

\section{Initial Chemical Events Caused by Carcinogenic Heterocyclic Amines and Molecular Design of Anti-tumor Agents}

\author{
YUICHI Hashimoto \\ Faculty of Pharmaceutical Sciences, University of Tokyo, \\ 7-3-1, Hongo, Bunkyo-ku, Tokyo, 113, Japan
}

\begin{abstract}
Initial chemical events caused by carcinogenic 2-amino-6-methyldipyrido[1,2-a: $\left.3^{\prime}, 2^{\prime}-d\right]$ imidazole (Glu-P-1) and molecular design of antitumor agents on the basis of the intercalative ability of Glu-P-1 skeleton are reviewed.

Glu-P-1 binds to deoxyribonucleic acid (DNA) at the 8-position of guanine residues after metabolic activations. Structures of modified nucleic acid base and the activated metabolites were confirmed by alternative synthesis. The pathway of chemical modification of DNA with Glu-P-1 is established chemicaly, and found to occur in vivo. The chemical modification of oncogene proto-ras caused transforming activity of the gene toward NIH3T3 cells. In other words, chemical modification of DNA with Glu-P-1 results in cell transformation. The established pathway of the DNA modification provides a fundamental standpoint in the study of chemical carcinogenesis caused by Glu-P-1.

Glu-P-1 possesses intercalative ability toward double stranded DNA. We designed and synthesized polyamino-Glu-P derivatives and Hemin-Glu-P-1 derivatives. PolyaminoGlu-P derivatives were found to possess extremely high affinity toward DNA. HeminGlu-P-1 derivatives cleaved DNA efficiently. Hemin-Glu-P-1 derivatives were suggested to cleave DNA in the same mode of reaction as bleomycin: Hemin-Glu-P-1's are functional analogs of bleomycin. The results suggested the possibility of the method of molecular design described might be served for the development of new antitumor agents.
\end{abstract}

Keywords - 2-amino-6-methyldipyrido[1,2- $\left.a: 3^{\prime}, 2^{\prime}-d\right]$ imidazole (Glu-P-1); DNA chemical modification; carcinogen; intercalation; DNA cleavage

\section{I. はじめに}

癌は医学・薬学・生物学・化学などの多岐に亘る分野に拈いて幅広くかつ精力的に研究されている対象であ る.一口に癌と言っても様々な癌があるように，その原因も様々なところに求められる．確立されている実験系 だけをみてもウイルス発癌, 化学発癌, 放射線による発癌, 刺激 (物理的刺激と食塩の組み合わせなど)による発 癌などが挙げられる．人癌の原因が洰としていずれに求められるかは別として, 癌の発症機構を化学的に研究す る上で化学発癌は優れた実験系であろう。化学発癌実験においてはしばしば人癌臨床例に酷似した癌が発生し， 職業癌の存在や疫学的知見は人癌においても化学発癌の占める割合が決して少なくないことを物語っている.こ のような観点から, 環境中に存在する発癌性化合物の検索が数年来精力的に行われいくつかの注目すべき事実が 明らかにされてきたそその 1 つは発癌性化合物の加熱調理食品中における存在である (Fig. 1). ${ }^{1)}$ 図に示す一連 の発癌性化合物はいずれも縮合三環性の複素芳香族アミンであり，へテロ原子の $\alpha$ 位にアミノ基を有する点で構

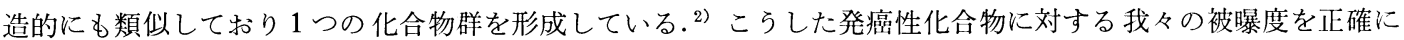
求めることはできないが, 通常成人が一日に掑取する各種発癌性複素芳香族アミンの総量は最大 $1.5 \mu \mathrm{g} / \mathrm{kg}$ 程度 であろらと推定されている. ${ }^{3}$ ) ちなみにこの量はマウスの発癌試験から求められた実質安全濃度 (発癌頻度の上 昇が 100 万個体に 1 個体の割合である濃度) の約 100 倍に相当する. ${ }^{3)}$ 筆者らはこれら発癌性複素芳香族アミンの

*本総説は昭和 61 年度日本薬学会奖励賞受賞業績を中心に記述したものである. 
<smiles>[R]c1[nH]c2ccccc2c1N</smiles>

$\mathrm{R}=\mathrm{CH}_{3}:$ Trp-P-1

$\mathrm{R}=\mathrm{H}: \quad$ Trp-P-2<smiles>[R]c1cccn2c1nc1ccc(N)nc12</smiles>

$\mathrm{R}=\mathrm{CH}_{3}:$ Glu-P-1<smiles>[R]c1cc2c(nc1N)[nH]c1ccccc12</smiles>

$\mathbf{R}=\mathbf{H}: \quad \mathbf{A} \alpha \mathbf{C}$<smiles>[R]c1cc2ncccc2c2nc(N)n(C)c12</smiles>

$\mathrm{R}=\mathrm{H}: \quad \mathrm{IQ}$

$\mathrm{R}=\mathrm{CH}_{3}: \mathrm{MeIQ}$<smiles>Cc1cnc2ccc3c(nc(N)n3C)c2n1</smiles>

MeIQx

Fig. 1. Carcinogens in Cooked Foods

代㴬活性化と deoxyribonucleic acid (DNA) 化学修飾に代表されると考光られる化学発癌初期過程4) 亿関する化 学研究を行ってきた．それは化学発癌に関する議論の多くが「DNA の化学修飾」といら現象の上に成立してお り，DNAの化学修飾過程に対して化学的に確実な解答を得ることはこれらの議論すべてに対して確たる立脚点 を与えることになると考えたからである，発癌性複素芳香族アミンによる DNA の化学修飾過程については既 にいくつかの総説 ${ }^{2,4-8)}$ を発表してあるので本総説では前半に筆者らの研究の中から 2-アミノ-6-メチルジピリド $\left[1,2-a: 3^{\prime}, 2^{\prime}-d\right]$ イミダゾール (Glu-P-1) に関するものを例にとり得られた解答を簡単に, 最近の研究成果を含め て概説する.

一方，筆者らは発癌研究は制癌研究に応用されるべきであると考劣てきた。多くの制癌剤はその標的が DNA であり, その点においても制癌研究と発癌研究は重複するところも多い. 研究の一例は制癌性抗生物質マイトマ イシンC と DNA との反応の解析， 3 種のマイトマイシンC 結合ヌクレオチドの構造決定 ${ }^{7-12)}$ であるが紙面の都 合により割愛する。いま1つの研究例は上述 Glu-P-1 の DNA 認識能に着目した新規制癌剂の分子設計であ る. ${ }^{13,14)}$ 多くの制癌剂が DNA に対して高い親和性を有すること，また主要な制癌剤の作用機作の1つとして DNA 鎖の切断が考兄られることから箻者らはより優れた DNA 認識能を有する Glu-P 誘導体 (ポリアミノー Glu-P) 及び DNA 鎖切断能を有する Glu-P-1 誘導体 (ヘミン-Glu-P-1)の分子設計を行ってきた. 本総説の後半 ではこれらの，DNA と相互作用する化合物に関する研究成果を概説する.

\section{Glu-P-1 による化学発癌初期過程}

II-1. 修飾核酸塩基の構造 Glu-P-1 は小菅・杉村らにより初めグルタミン酸熱分解物中より変異原性を指 標として単離された発癌性化合物である. ${ }^{15-17)}$ Glu-P-1 による化学発癌は DNA 化学修飾により惹起される一連 の生化学的反応が原因の 1 つ考えられるが，DNAの化学修飾に対する直接的な解答は修飾された DNA（部 分）構造を決定してはじめて与えられる.そこでまず in vitro で Glu-P-1 とよる DNA 化学修飾を行い, 修飾 核酸塩基の構造決定を行った。

Glu-P-1 は变異原性発現に代謝酵素系の存在が必要であるが，これに対応して代謝酵素系の存在下にはじめて DNA に共有結合する.この DNA 化学修旍は極めて特異的であり, 得ら机る修飾 DNA を加水分解すると修飾 核酸塩基として Gua-Glu-P-1 のみが得られた. Gua-Glu-P-1 を強アルカリにより更に加水分解すると収率よく 㲾酸と Glu-P-1 が生成した (Chart 1).この結果及び Gua-Glu-P-1 の各種スペクトルデータから Gua-Glu-P-1

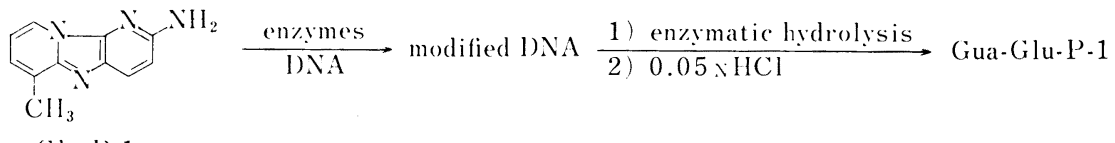

(ilu-l'-1

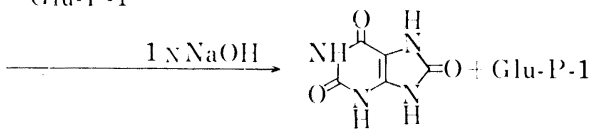

Chart 1. Formation and Degradation of Gua-Glu-P-1 


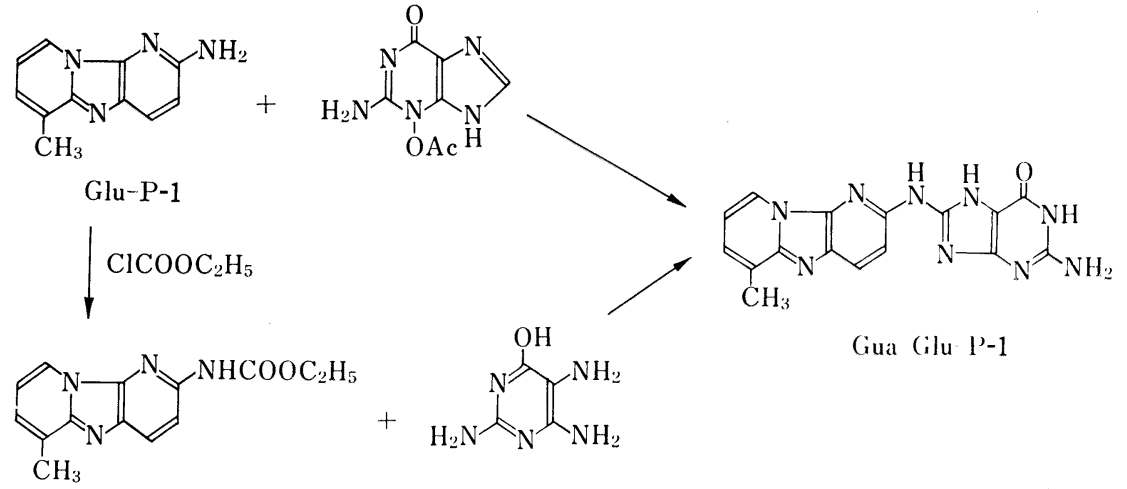

Chart 2. Synthesis of Gua-Glu-P-1

の構造を 2-(グアニン-8-イル)アミノ-6-メチルジピリド[1,2-a: $\left.3^{\prime}, 2^{\prime}-d\right]$ イミダゾールと推定し別途合成品との比較 からこの構造を確認した. ${ }^{18,19)}$ 別途合成は Glu-P-1 の3-アセトキシグアニンに対する8 位炭素求核置換反応 ${ }^{20,21)}$ 及び2-カルボエトキシアミノ-6-メチルジピリド[1,2-a: $\left.3^{\prime}, 2^{\prime}-d\right]$ イミ゙ン゙ールと 1,2,5-トリアミノー6-トドロキシヒ リミジンとの縮合環化反応により行った (Chart 2). これらの反応はグアニンの 8 位炭素に発癌性芳香族アミン のアミノ基窒素が結合した修飾核酸塩基の一般的合成法として有用であり, 本法により 3-アミノー1-メチル-5H-ヒ リド[4,3-b]インドール (Trp-P-2), ${ }^{22,23)}$ ナフチルアミン ${ }^{24)} 1$ ーニトロピレン ${ }^{25)}$ などにより修飾された核酸塩基の合 成と同定が成功している.

II-2. 代謝活性体の構造前節に述べた修飾核酸塩基 Gua-Glu-P-1 の構造は 1) 系としての酸化状態がもと の系に比して一段階上昇していること，2) グアニンの 8 位炭素が DNA 中の求核中心の 1 つであることなどから Glu-P-1 の代謝活性化の中間体が対応するヒドロキシルアミン，2-ヒドロキシアミノ-6-メチルジピリド[1,2- $a$ : $\left.3^{\prime}, 2^{\prime}-d\right]$ イミダゾール (N-OH-Glu-P-1) であることを示唆する. 芳香族ヒドロキシルアミン誘導体は N-O 結合 のへテロリシスにより炭素求核試薬による攻撃を受けることが確立している. ${ }^{26)}$ そこで Glu-P-1 をラット胙より 調製したミクロゾーム分画で処理し代謝産物を検索した。 その結果, 唯一の主代謝産物として N-OH-Glu-P-1 を 別途合成品との比較から確認することができた. ${ }^{19,27)}$ 別途合成は Chart 3 に示す方法により行った。一般に芳香<smiles>Cc1cccn2c1nc1ccc(N)nc12</smiles>

Glu-P.1

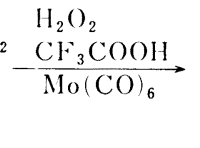<smiles></smiles>

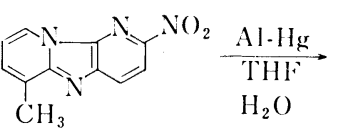
$\mathrm{H}_{2} \mathrm{O}$<smiles>Cc1ccc[Y]c2c3nc([Al]=O)ccc3cc1-2</smiles>

N.()H-(ilu-P.1

\section{Chart 3. Synthesis of N-OH-Glu-P-1}

族ヒドロキシルアミンを対応するアミンの酸化により得ることは困難であるため, Glu-P-1 を一旦対応するニト 口化合物に酸化し, 次いで部分還元する方法を計画した. Glu-P-1 は種々酸化条件を検討した結果, 過酸化水㨞一 トリフロロ酢酸ーモリブデンヘキサカルボニルーメチレンクロリドといら複雑な系で $80-90 \%$ の収率で対応する ニトロ化合物に酸化できた．これを含水テトラヒドロフラン中，アルミニウムアマルガムにて還元することによ り N-OH-Glu-P-1 を得ることができた.この還元反忘は 2-ヒドロキシアミノピリジン系や 2-ヒドロキシアミ， イミダゾール系などの不安定なヒドロキシルアミン誘導体の合成に有用な一般的方法であると考えている. ${ }^{28,289}$ 合成した N-OH-Glu-P-1 の構造は元素分析, 核磁気共鳴スペクトル (NMR), 質量分析, 紫外線吸収スペクトル (UV) などにより確認し，更にニトロソベンゼンとの反応によりフェニルアゾキシ誘導体に導いてヒドロキシル アミノ基の存在を確認した (Chart 3). 
II-3. N-OH-Glu-P-1 と DNA との反応前項で Glu-P-1 の代謝産物としての N-OH-Glu-P-1 の合成と同 定について述べた. N-OH-Glu-P-1 が Glu-P-1 による DNA 化学修飾過程における代謝活性化の中間体である ことを証明するために，合成した純粋な N-OH-Glu-P-1 を用いて DNA との反応を検討した。

N-OH-Glu-P-1 それ白身は中性条件に打いても弱酸性条件においても DNA と反応しないいわゆる proximate form (DNA の化学修飾にお壮る代謝活性化過程の中間体) であることが分かった. そこで更なる代謝活 性化として, ヒドロキシルアミノ基 N-O 結合のへテロリシスを大きく促進することが確立している O-アシル 化 ${ }^{28)}$ の寄与を推定した. 実際, N-OH-Glu-P-1 をケテンもしくは無水酢酸によりO-アセチル化し2-アセトキシアミノー6-メチルジピリド[1,2- $\left.a: 3^{\prime}, 2^{\prime}-d\right]$ イミダゾール(N-OAc-Glu-P-1) とすると中性条件下でも効率よく DNA と反応する. 得られる修飾 DNA を加水分解すると, in vitro で生成したのと同じ Gua-Glu-P-1 が唯一の主修飾

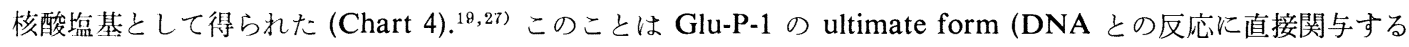
究極の代謝活性体) が N-OH-Glu-P-1 の水酸基がアシル化されたものであることを強く示唆している. 生体内に おケる O-アシル化としてはアセチル化, スルホン化, ホスホリル化など種々考えられるが, 最近加藤らにより N-OH-Glu-P-1 の O-ア七チル化が示されている. ${ }^{30)}$ いずれにしても Glu-P-1 の代謝を Glu-P-1 が DNA を化学 修飾するために必要な化学変換の過程として捉えるかぎり，N-水酸化による N-OH-Glu-P-1 の生成とそれに引 き続くO-アシル化といらことで充分に必要な解答が一義的に得られたものと考えている.<smiles>Cc1cccn2c1nc1ccc(NO)nc12</smiles>

$\mathrm{N}-\mathrm{OH}-\mathrm{Glu}-\mathrm{P}-1$<smiles>[3H]C(C)(C)[13N]</smiles>

modified DNA

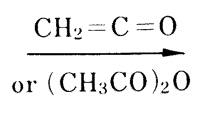<smiles>Cc1cccn2c1nc1ccc(NOC(=O)O)nc12</smiles>

$\mathrm{N}-\mathrm{OAc}-\mathrm{Glu}-\mathrm{P}-1$

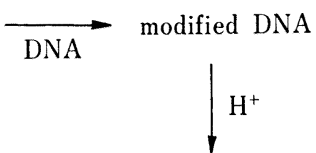<smiles>Cc1cccn2c1nc1ccc(Nc3nc4nc(N)[nH]c(=O)c4[nH]3)nc12</smiles>

Gua-Glu-P-1

Chart 4. Reaction of N-OH-Glu-P-1 with DNA

II-4. 生体内における Glu-P-1による DNA 化学修飾以上述べてきたように Glu-P-1 による DNA 化学修 飾の過程は化学的に再現することができとの実体が明らかとなった．同様の DNA 化学修飾が生体内で生じてい ることを確認することは Glu-P-1 による化学発癌過程を論じる上に打いても重要である．筆者らは Glu-P-1 をラ ットに腹腔内投与し, 朋 DNAを抽出して分析した。 その結果, 唯一の主修飾核酸塩基として Gua-Glu-P-1 を 確認することができ，上述の Glu-P-1 による DNA 化学修飾と同様の過程が生体内に颃いても起こっていること を証明した. ${ }^{31)}$ Glu-P-1 の結合量は $25 \mathrm{mg} / \mathrm{kg}$ の投与量の時に約 20 万ヌクレオチドに 1 分子の割合でありこの 值は投与後 8-48 時間の間ではほぼ一定であった。

II-5. インターカレーションの重要性Ｇlu-P-1 の ultimate form(の1つ) である N-OAc-Glu-P-1 とグア ニン関連化合物との反応を検討したところ, Glu-P-1 骨格の DNA 塩基対間への平行な挿入 (インターカレーシ ョン)の重要性が示唆された.すなわり, N-OAc-Glu-P-1 は二重らせん DNA や相補的ジヌクレオチドであるグ アニル $\left(3^{\prime} \rightarrow 5^{\prime}\right)$ シチジンとは効率よく反応し, 加水分解により Gua-Glu-P-1 を与えるが一本鎖 DNA, ポリグア

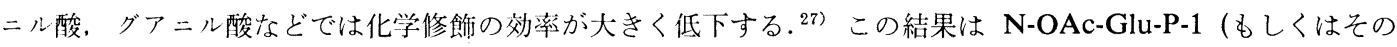
N-O 結合のへテロリシスにより生じたカチオン種) のインターカレーションがグアニンとの共有結合形成にと って好都合なためと解釈できる. 実際, N-OAc-Glu-P-1 と DNA との反応に際して G-C 塩基対に選択的なイン ターカレーターであるダゥノマイシンを共存させると Gua-Glu-P-1 の生成収率が低下する. ${ }^{37)}$ N-OAc-Glu-P-1 とグアニン残基との反応による Gua-Glu-P-1 の生成は芳香族求電子置換反応であり, 中間体として $\pi$ 錯体を経 由すると考兄られる. Glu-P-1 骨格の DNA へのインターカレーションにより生ずる複合体のコンフォメーシ 
ョンはこの $\pi$ 錯体もしくはそれに近いコンフォメーションを有するものと推定される.このことは山口・板井ら

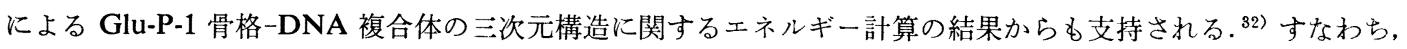
Glu-P-1 骨格-DNA 複合体のエネルギー的に最も安定なコンフォメーションにおいては反応中心である Glu-P-1 の 2 位アミノ基窒素とグアニンの 8 位炭素とが近い位置にある. ${ }^{4)} こ の$ 状態から $\pi$ 錯体, 次いで $\sigma$ 錯体を経由し て Glu-P-1 結合 DNA (Gua-Glu-P-1-DNA) を生成する過程においては, Glu-P-1 骨格は DNA二重らせん内に 他の塩基対と平行に配向してとどまり，グアニン残基が DNA 二重らせんの外側にとび出す(インターカレーテ ィヴ共有結合) と考えている.このインターカレーティヴ共有結合は, Glu-P-1 骨格に由来するケイ光スペクトル

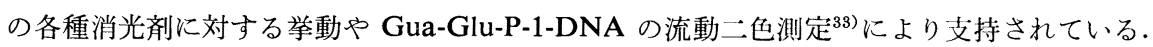

なお, Glu-P-1 骨格と DNA との物理的相互作用については今村らにより詳細に検討され, 以下の絬果から Glu-P-1 骨格のインターカレート能が証明されている.すなわち, 1) Glu-P-1 の DNA 共存下に打学外線叫 収やヶイ光の濃度依存的な变化から $10^{4} \mathrm{M}^{-1}$ 程度の結合定数が得られた, $\left.{ }^{34)} 2\right)$ 流動二色法により, DNAに物理 的に結合している Glu-P-1 は DNA の塩基対と平行に配向していることが確認された, ${ }^{35)} 3$ ) 超らせん環状 DNA の巻き戻し実験により, DNA に物理的に Glu-P-1 が結合すると 1 分子当り $20-25^{\circ}$ の DNA二重らせん巻き 戻しを起こすことが示された. ${ }^{34)}$

II-6. Glu-P-1 による DNA 化学修飾の塩基配列選択性 前項で Glu-P-1 による DNA 化学修飾が Glu-P-1 骨格のインターカレーションにより大きく促進されていることを示した. DNA にインターカレートして反応す る化合物は塩基配列選択性を示す可能性がある. 一方, 筆者らは Gua-Glu-P-1-DNA の化学的性質として, GuaGlu-P-1 部分のグリコシド結合が選択的に加水分解できることを見い出した.すなわち, Gua-Glu-P-1-DNA は その水溶液を加熱すると Gua-Glu-P-1 が定量的に遊離する.これをピペリジン存在下で行えば, DNA は Gua-

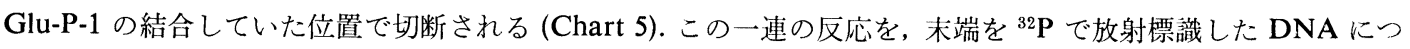
いて行い, 生成するDNA 断片をマクサム・ギルバート法帛) と併用して塩基配列決定用ゲル電気泳動で分析すれ ば, Glu-P-1 の結合位置が塩基配列のレベルで決定できる. ${ }^{37,38)}$ 結果を Fig. 2 に示す. 星印が Glu-P-1 による修 飾頻度を示している． CもしくはGにはさまれた G 度は低い. 言い換えると Glu-P-1 によるグアニン残基に特異的な DNA 化学修飾は G-C rich region にあるグ アニンに選択的であると言える.この塩基配列選択性は, Ames 試験におけるサルモネラ菌 TA 98 の突然変異に かかわる部分塩基配列や, 後述する腫瘍遺伝子 r a s の活性化にかかわる点突然変異の部分塩基配列が比較的 GC rich であることを考古とその生物学的意味は小さくないと思われる.<smiles>Cc1cccn2c1nc1ccc(Nc3nc4c(=O)[nH]c(N)nc4n3C3CC(OP(=O)(O)O[Al])C(C)O3)nc12</smiles><smiles>Cc1cccn2c1nc1ccc(Nc3nc4nc(N)[nH]c(=O)c4[nH]3)nc12</smiles>

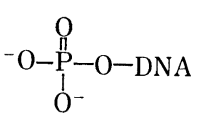<smiles>CCC(C)O</smiles><smiles>O=[W]([O-])([18O])O[Na]</smiles>

Chart 5. Cleavage of DNA at the Glu-P-1 Bound Sites 


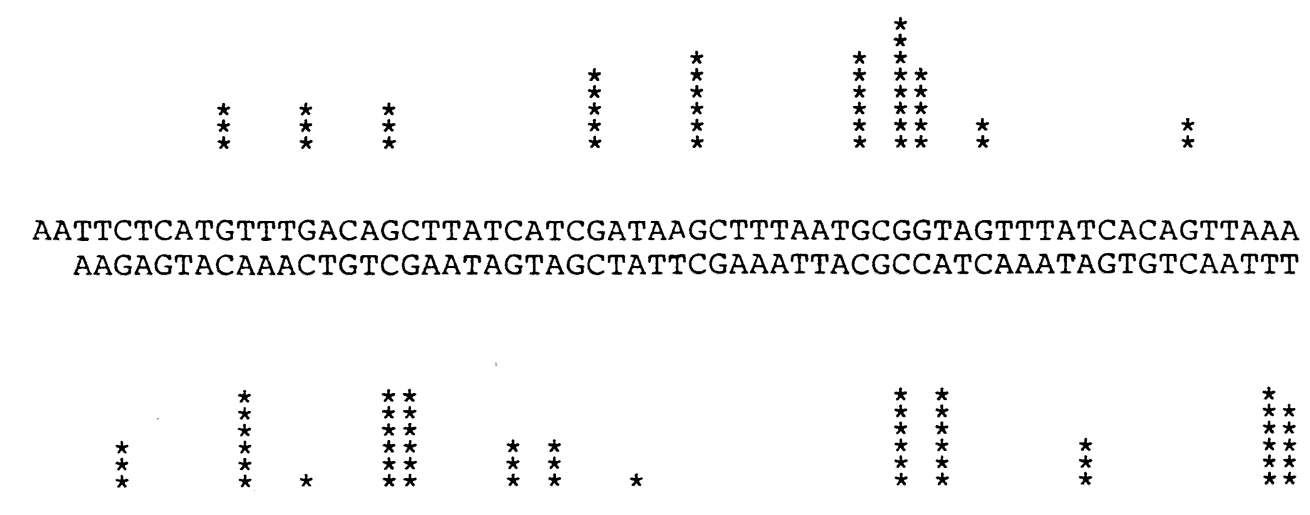

TTGCTAACGCAGTCAGGCACCGTGTATGAAATCTAACAATGCGCTCATCGTCATCCTCGG AACGATTGCGTCAGTCCGTGGCACATACTTTAGATTGTTACGCGAGTAGCAGTAGGAGCC

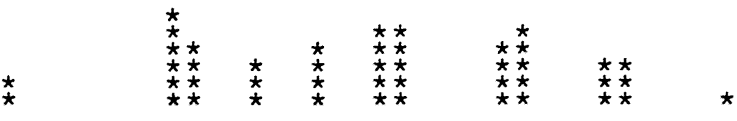

\section{CACCGTCACCCTGGATGCTGTAGGCATAGGCTTGGTTATGC GTGGCAGTGGGACCTACGACATCCGTATCCGAACCAATACG}

Fig. 2. Base-Sequence-Selective Modification of DNA with N-OAc-Glu-P-1 * = relative probability of modification with N-OAc-Glu-P-1.

II-7. 腫場遺伝子 ras の化学修飾による活性化 以上, Glu-P-1 による DNA の化学修飾過程を Glu-P-1 に よる化学発癌の初期過程であるとして述べてきた.この DNA 化学修飾過程は化学的に確立したものであり,生 体内でも生じていることを証明したが, それが細胞癌化の直接の原因であることの科学的証明はない，それは細 胞の癌化が成立するまでの数々のステップが生物学的・生化学的にも解明されていないからであるが, 最近の腫 瘍遗伝子に関する研究は極めて示唆的である. 現在までに 20 種以上の腫瘍遺伝子が報告されているが, 細胞癌 化はそれら腫煌遺伝子のうちのいくつかが活性化（細胞をトランスフォーメーションさせるといら意味で） し協 同作用した結果として捉えることができる. ${ }^{39)}$ 筆者らが注目したのは $H$-ras といら腫瘍遗伝子である. ヒト正常 組織由来の H-ras (proto-ras) は繁用される検定細胞であるマウス繊維芽細胞 NIH3T3 をトランスフォームする 活性を持たないが，ヒト腫瘍組織由来の H-ras (c-ras) はしばしば NIH3T3 に対してトランスフォーメーション 活性を有している.そしてこの非活性型な proto-ras と活性型の c-ras の違いは 12 番目あるいは 61 番目などの

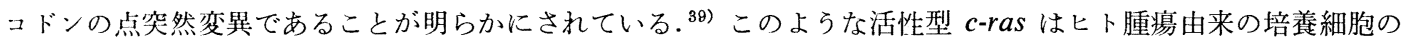

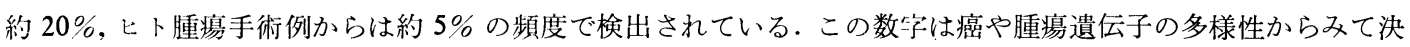
して低い值ではなかろう. Proto-ras の点突然変異によるトランスフォーメーション活性の獲得, すなわち protoras の活性化, の細胞癌化過程における位置は諸説紛々としていて確立していないが, 筆者らは proto-ras の活性 化が化学発癌の原因の 1 つであると考光て良いと捉えている. そこで Glu-P-1 による proto-ras の化学修飾が proto-ras のトランスフォーメーション活性獲得の原因となることを証明しょらとした．以下にその研究成果を 述べるが，用いた腫惶遗伝子はすべて国立がんセンター研究所 関谷剛男博士より供与して頂いたものである.

遗伝子に対して Glu-P-1 による化学修飾が生ずるとその機能が損われることは子想できる，そこでまず，ヒト メラノーマ由来の活性型 $H$-ras を組み迄んだプラスミド pSK240) を反応基質として N-OAc-Glu-P-1 と反応さ せ, 得られる Glu-P-1 結合 pSK2 2 \&IH3T3 にトランスフェクトし, そのトランスフォーメーション活性を測 定した (Table I). ${ }^{41,42)}$ 予想したと㧍り，Glu-P-1 の結合量の増加に伴い Glu-P-1 結合 pSK2 のトランスフォー 
TABLE I. Effect of Reaction with N-OAc-GluP-1 on Transforming Activity of pSK2

\begin{tabular}{rlc}
\hline $\begin{array}{c}\text { DNA/N-OAc- } \\
\text { Glu-P-1 }\end{array}$ & $\begin{array}{c}\text { Binding } \\
\text { amount }\end{array}$ & $\begin{array}{c}\% \text { of transforming } \\
\text { activity remaining }\end{array}$ \\
\hline $1: 0$ & 0 & $100(=630$ foci $/ \mu \mathrm{g})$ \\
$300: 1$ & $1 / 10000$ & 45 \\
$30: 1$ & $1 / 1200$ & 97 \\
$3: 1$ & $1 / 400$ & 42 \\
$1: 3$ & $1 / 400$ & 40 \\
$1: 30$ & $1 / 200$ & 3 \\
\hline
\end{tabular}

TABLE II. Induction of Focus-Forming Activity Following Reaction of N-OAc-Glu-P-1 with Plasmid Containing Proto-H-ras (pSVMBras-gpt)

\begin{tabular}{clcc}
\hline $\begin{array}{c}\text { DNA/N-OAc- } \\
\text { Glu-P-1 }\end{array}$ & $\begin{array}{c}\text { Binding } \\
\text { amount }\end{array}$ & $\begin{array}{c}\text { Total foci/ } \\
\text { total plates }\end{array}$ & foci/ $/ \mathrm{g}$ \\
\hline $1: 0$ & 0 & $(1) / 4$ & $0(0.01)$ \\
$30: 1$ & $1 / 1500$ & $30 / 8$ & 0.15 \\
$3: 1$ & $1 / 500$ & $2 / 8$ & 0.01 \\
$1: 3$ & $1 / 400$ & $9 / 8$ & 0.05 \\
\hline
\end{tabular}

メーション活性は低下し, 200 ヌクレオチドに一分子の結合量ではほとんどトランスフォーメーション活性が失 われる．この結果を参考に反応条件を設定し，proto-ras と等価な塩基配列を有する pSVMB ${ }_{\text {ras-g }} t^{43}$ をを用いて同 様の実験を行った (Table II). ${ }^{41,42)} \mathrm{pSVMB}_{\text {ras-gpt }}$ そのものには当然のことながらほとんどトランスフォーメー ション活性が無いが, これに化学的に Glu-P-1 を結合させて調製した修飾 DNA には確実にトランスフォーィー ション活性が認められた。このことは, Glu-P-1 による DNA 化学修飾が proto-ras の活性化の直接の原因であ ることを確実に証明したことになる。化学的に確立してあり生体内でも生じていることを証明してある Glu-P-1 による DNA 化学修飾過程を化学的手法で完成させ, 得られる修飾 DNA 細胞内で発現させて細胞をトランス フォームさせたといら意味で細胞の癌化過程をある程度人工的に再現できたものと考えている.

生じたトランスフォーマントにおいては, Glu-P-1 による化学修飾の結果として突然変異を生じトランスフォ 一メーション活性を獲得した proto-ras が発現していると考えられる。その一部は 11-12 番目のコドンにおける 突然変異であることが, 制限酵素 $M s p I$ を用いた加水分解実験から示唆されている. 他のものについてはトラン スフォーメーション活性の獲得がいかなる突然変異に帰因するものであるかを現在検討中である.

II-8. 総括 以上, Glu-P-1 による化学発癌初期過程について得られた解答は Chart 6 に示される. Glu-P-1 はまず N-水酸化を受け，さらに O-アシル化された後に DNA と反応し Gua-Glu-P-1 を与える. この反応は DNA 中グアニンの 8 位炭素に特異的であり, 修飾されるグアニンは G-C rich region にあるグアニンに選択的 である.この過程に括いて Glu-P-1 骨格のインターカレート能は重要な因子となっており, Glu-P-1 の DNAに 対する結合はインターカレーティヴ共有結合である.この DNA 化学修飾は突然变異の直接的原因であり, proto-ras の化学修飾はトランスフォーメーション活性の獲得に市る. 言い換えると, Chart 6 にホす Glu-P-1 によ る DNA の化学修飾過程は化学発癌の直接の原因である.<smiles>Cc1cccn2c1nc1ccc(N)nc12</smiles>

Glu-P-1

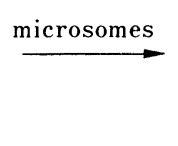<smiles>Cc1cccn2c1nc1ccc(NO)nc12</smiles>

$\mathrm{N}-\mathrm{OH}-\mathrm{Glu}-\mathrm{P}-1$<smiles>Cc1cccn2c1nc1ccc(NOC#N)nc12</smiles>

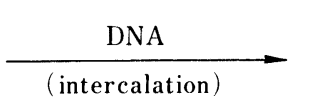<smiles>Cc1cccn2c1nc1ccc(N)nc12</smiles>

Gua-Glu-P-1-DNA

Chart 6. Initial Events Caused by Carcinogenic Glu-P-1

もちろん, 発癌プロモーターやそのモジュレーターなどのエピジェネティックな問題は細胞の癌化過程におい てまた別の大変重要な課題であるし, 腫瘍遺伝子産物の生物活性やその作用機作, 細胞増殖因子とのかかわりな ぞ多くの課題についての研究が急速に進行しつつある. 


\section{III. ポリアミノ-Glu-P 誘導体}

III-1. デザインと合成発癌研究は制癌研究に応用されるべきである，筆者らが着目したのは Glu-P 骨格 のインターカレート能である.多くの制癌剤は DNA にインターカレートすることにより作用を発現すると考觉 られており，インターカレーションに着目した制癌剤開発の試みは広く行われている. ${ }^{14)}$ そこで筆者らはより優 れた DNA 認識能を有する Glu-P 誘導体を得ることを目的とした研究を行ってきた.

Glu-P 骨格の DNA ヘのインターカレート能を生かしつつより優れた DNA 認識能を有する化合物へ誘導す る方法として次の 3つが考えられる. 1) Glu-P 骨格そのものを，より DNA 塩基対間空間にフィットする分子型 に変換する，2) Glu-P 骨格に対してそのインターカレート能を損らことなくDNA に対して親和性を有する置換

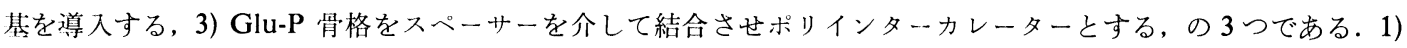
の Glu-P 骨格の改変は, DNA にインターカレートして生ずる複合体のコンフォメーションの問題などに遭遇 し, 分子設計が困難である.一例は, 強力なインターカレーターである制癌剤エリプチシンとの構造的関連から 考案したベンゾ-Glu-P 誘導体である. Fig. 3 に構造とその DNA との結合定数を示すが, 6,7-ベンゾ-Glu-P 誘 導体のみが Glu-P-2 の約 10 倍の DNA 親和性を有していた. ${ }^{44)}$ 上述 2) 及び 3) のタイプとして筆者らは DNA に対して高い親和性を有するスペルミンなどのポリアミンを Glu-P 骨格に導入したポリアミノ-Glu-P 誘導体 (GP-Sp, 2GP-Sp, 2GP-Spd) を Chart 7 に示す方法により合成した. ${ }^{13,45)}$ Glu-P 骨格の N-アルキル化の位置は これらの化合物を 2-ブロムジピリド[1,2-a: $\left.3^{\prime}, 2^{\prime}-d\right]$ イミダゾールから別途合成して確認した.

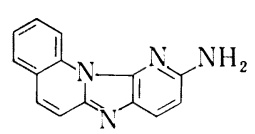

$K=0.24 \times 10^{4} \mathrm{M}^{-1}$

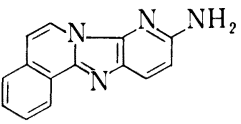

$K=20.00 \times 10^{4} \mathrm{M}^{-1}$<smiles></smiles>

$K=0.03 \times 10^{4} \mathrm{M}^{-1}$

Fig. 3. Structure of Benzo-Glu-P's and their Binding Constants to DNA

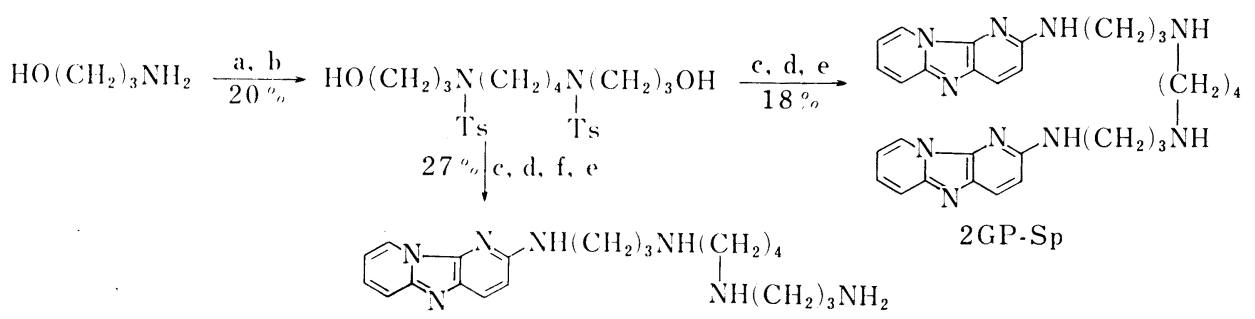

(iI'SI' $\mathrm{NH}\left(\mathrm{CH}_{2}\right)_{3} \mathrm{NH}_{2}$

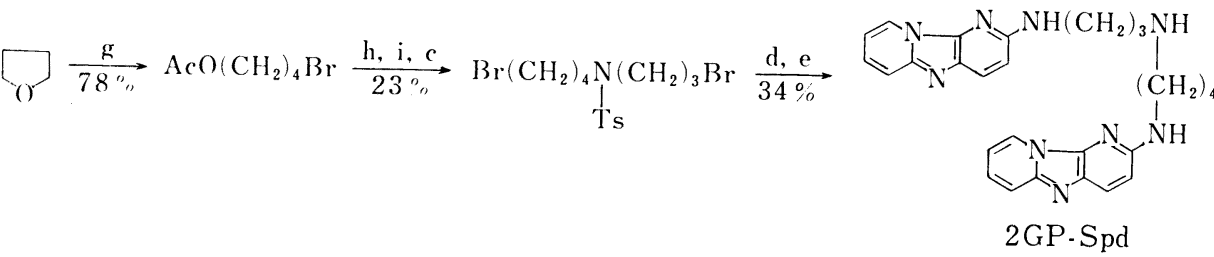

Chart 7. Synthesis of Polyamino-Glu-P-Derivatives a: $\mathrm{TsCl}, \mathrm{K}_{2} \mathrm{CO}_{3}$, DMF; b: $\mathrm{Br}\left(\mathrm{CH}_{2}\right)_{4} \mathrm{Br}$, DMF; c: $\mathrm{SOBr}_{2}, \mathrm{CHCl}_{3}$; d: N-Tosyl-Glu-P-2, NaH, DMF: e: $47 \%$ $\mathrm{HBr}$; f: $\mathrm{NH}_{3}$, EtOH; g: $\mathrm{ZnCl}_{2}, \mathrm{AcBr}$; h: $\mathrm{TsNH}\left(\mathrm{CH}_{2}\right)_{3} \mathrm{OH}, \mathrm{NaH}, \mathrm{DMF}$; i: $\mathrm{HCl}, \mathrm{MeOH}$.

1II-2. DNA との物理的相互作用梁リアミノ-Glu-P 誘導体の DNA との物理的相互作用には複数の相互 作用様式が存在する。このため, DNA との親和性の尺度として DNA にインターカレートしているエチジゥム ブロミドを $50 \%$ 追い出す濃度 $\left(C_{50} \text { 值 }\right)^{21,48)}$ を測定した (Table III). ${ }^{45)}$ ポリアミノ-Glu-P 誘導体はいずれも対 伈する Glu-P 骨格, 2-アミノジピリド[1,2-a: 3',2'-d]イミダゾール (Glu-P-2) に比して極めて高い親和性を有し ている、ポリアミン部分の構造は DNA に対する親和性に大きく影響し，2GP-Sp のスペルミン部分をスペルミ ジンに㯰き換えた 2GP-Spd は 2GP-Spの 1/50 程度の DNA 親和性しか持たない.ポリアミノ-Glu-P 誘導体と 
TABle III. $C_{50}$ Values $^{a)}$ for Ethidium Displacement

\begin{tabular}{lc|lc}
\hline \hline \multicolumn{1}{c|}{ Drug } & $\begin{array}{c}C_{50} \\
(\mu \mathrm{mol})\end{array}$ & \multicolumn{1}{c}{ Drug } & $\begin{array}{c}C_{50} \\
(\mu \mathrm{mol})\end{array}$ \\
\hline EtBr & 1.25 & 2GP-Sp & 0.11 \\
Glu-P-2 & 1100 & GP-Sp & 0.13 \\
Spermine & 0.23 & 2GP-Spd & 6.5 \\
Spermidine & 1.00 & Spermine + & 0.24 \\
& & Glu-P-2 & \\
\hline
\end{tabular}

a) $C_{50}$ value was defined as a micro-molar concentration of added drug necessary to displace $50 \%$ of the DNAbound $\mathrm{EtBr}$ (calf thymus DNA; $0.98 \mu \mathrm{M}, \mathrm{EtBr} ; 1.25 \mu \mathrm{M}$, in $1 \mathrm{~mm}$ phosphate buffer, pH 7.3) and measured by the fluorescence intensity of DNA-bound ethidium (excited at $546 \mathrm{~nm}$, emitted at $655 \mathrm{~nm}$ ).

b) Glu-P-2 was added twice as molar amount of spermine.
TABLE IV. Melting Temperature $\left(T_{\mathrm{M}}\right)$ of Calf Thymus DNA ${ }^{a}$

\begin{tabular}{lc|lc}
\hline \multicolumn{1}{c}{ Drug } & $T_{\mathrm{M}}\left({ }^{\circ} \mathrm{C}\right)$ & \multicolumn{1}{c}{ Drug } & $T_{\mathrm{M}}\left({ }^{\circ} \mathrm{C}\right)$ \\
\hline None & 70.0 & 2GP-Sp & 83.5 \\
EtBr & 76.1 & GP-Sp & 82.5 \\
Glu-P-2 & 71.5 & 2GP-Spd & 71.8 \\
Spermine & 78.5 & Spermine + & 78.6 \\
\hline
\end{tabular}

a) In $0.1 \mathrm{SSC}\left(0.015 \mathrm{M} \mathrm{NaCl}, 0.0015 \mathrm{M} \mathrm{Na} \mathrm{Na}_{3}\right.$-citrate, calf thymus DNA; $4.29 \times 10^{-2} \mathrm{mmol} P$, drug; $\left.4.29 \times 10^{-3} \mathrm{~mm}\right)$. b) Spermine $\left(4.29 \times 10^{-3} \mathrm{~mm}\right)$ and Glu-P-2 $(8.58 \times$ $10^{-3} \mathrm{~mm}$ ).

DNA とで形成される複合体の安定性の指標として，ポリアミノ-Glu-P 誘導体の二重らせん.DNA の融解温度 $\left(T_{\mathrm{M}}\right)$ に与える効果を測定した (Table IV). ${ }^{45)}$ ポリアミノ-Glu-P 誘導体の DNA 二車らせん構造安定化能はこれ らの化合物の DNA 親和性 (Table III) によく対応している.

2GP-Sp などの Glu-P 二量体はビスインターカレーターであると期待できる.例藤らは 2GP-Sp の DNA 其 存下におけるケイ光寿命を測定し，2GP-Sp が一分子の DNA にビスインターカレートすることを示した. ${ }^{47)}$

これらのポリアミノ-Glu-P 誘導体は, 培養細胞 (HeLa 細胞) に対して増殖阻害作用を示し, DNA ポリ 一ゼ $\alpha$ によ DNA 複製系も阻害する. ${ }^{48)}$ なお, ポリアミノ-Glu-P 誘導体は Ames 試験において变異原性を六 さない. ${ }^{49)}$

\section{IV. ヘミン-Glu-P-1 誘導体}

IV-1. デザインと合成ＤNA 鎖の切断は主要な制癌剤の作用機作の 1 つである。そこで DNA を認識な るインターカレーターである Glu-P-1 に DNA 鎖を切断する機能を組み込んだ化合物を得ようとした. DNA 鎖 切断を主たる作用機作とする制癌剤の代表はブレオマイシンであると思われるが, ${ }^{50)}$ ブレオマイシンは (i) DNA にインターカレートするビスチアゾール環部分, (ii) 主として鉄に配位し, DNA 鎖切断に係わる活性酸素種発怆 の触媒となるペプチド鎖部分，及び (iii) 膜透過に係わるとされている糖部分，からなるとみられる。このよらな ブレオマイシンの構造と機能に関する考察はインターカレーターである Glu-P-1 に腫愓組織に絸和性を有する ことが知られており，かつ酸素活性化の触媒になりらるへミン鉄を結合させた化合物，へミン-Glu-P-1 (Charts 8, 9) が DNA 鎖切断能を有する可能性を示唆している. ${ }^{13,14)}$ そこで筆者らは一速のへミン-Glu-P-1 を Chart 8 文 び 9 に示す方法により合成した. ${ }^{51,52)} \mathrm{H}_{n} \mathrm{G}(n=2-4)$ 及び $\mathrm{H}_{n} \mathrm{G}_{2}(n=2-4)$ はそれぞれ Glu-P-1 部分とへミン鉄 部分を連結するスペーサーであるィチレン鎖の長さが異なるへミン-モノインターカレーター及びヘミンービスイ ンターカレーターである. Chart 9 に示す H4G-His 及び H4G-Im はそれぞれへミン・モノインターカレーター. である H4G に, 更にへミン鉄の第 5 配位子となり得る官能基, ヒスチジン及びプロピルイミダゾールをも組み 込んだ化合物である。これらの化合物の純度及び構造は元素分析, 質量分析, 紫外吸収スペクトル, 核磁気共鮚 スペクトル，高速液体クロマトグラフィー，薄層クロマトグラフィー及び電気泳動により確認した.

IV-2. DNA 鎖切断活性合成したへミン-Glu-P-1 誘導体の DNA 鎖切断能は, 超らせん環状 DNAの開 環状 DNA への変化として测定できる. Table Vに超らせん環状 DNA の DNA 鎖が切断されて生ずる開環状 DNA の収率を示す. ${ }^{52)}$ ヘミン-Glu-P-1 誘導体による効率の良いDNA 鎖切断にはへミン鉄を 2 価に保つために 還元剤の共存が有効であるので，ここではハイドロサルファイトナトリウムを加えてある。へミン-Glu-P-1 誘售 体はいずれもDNA 鎖切断能を有するが，特に分子内にへミン鉄の第 5 配位子になりうる官能基を組み込んだ化 合物, H4G-His 及び H4G-Im はブレオマイシンの $1 / 2-2 / 3$ という強い DNA 鎖切断能を有している.ヒスチジ ン部分やイミダン゙ール部分による DNA 鎖切断话性上昇の効果は, 単に H4G ととスチジンやイミダゾールを湜 合しただけでは再現できず，これたの官能基は同一分子内に組み込まれている必要がある。 

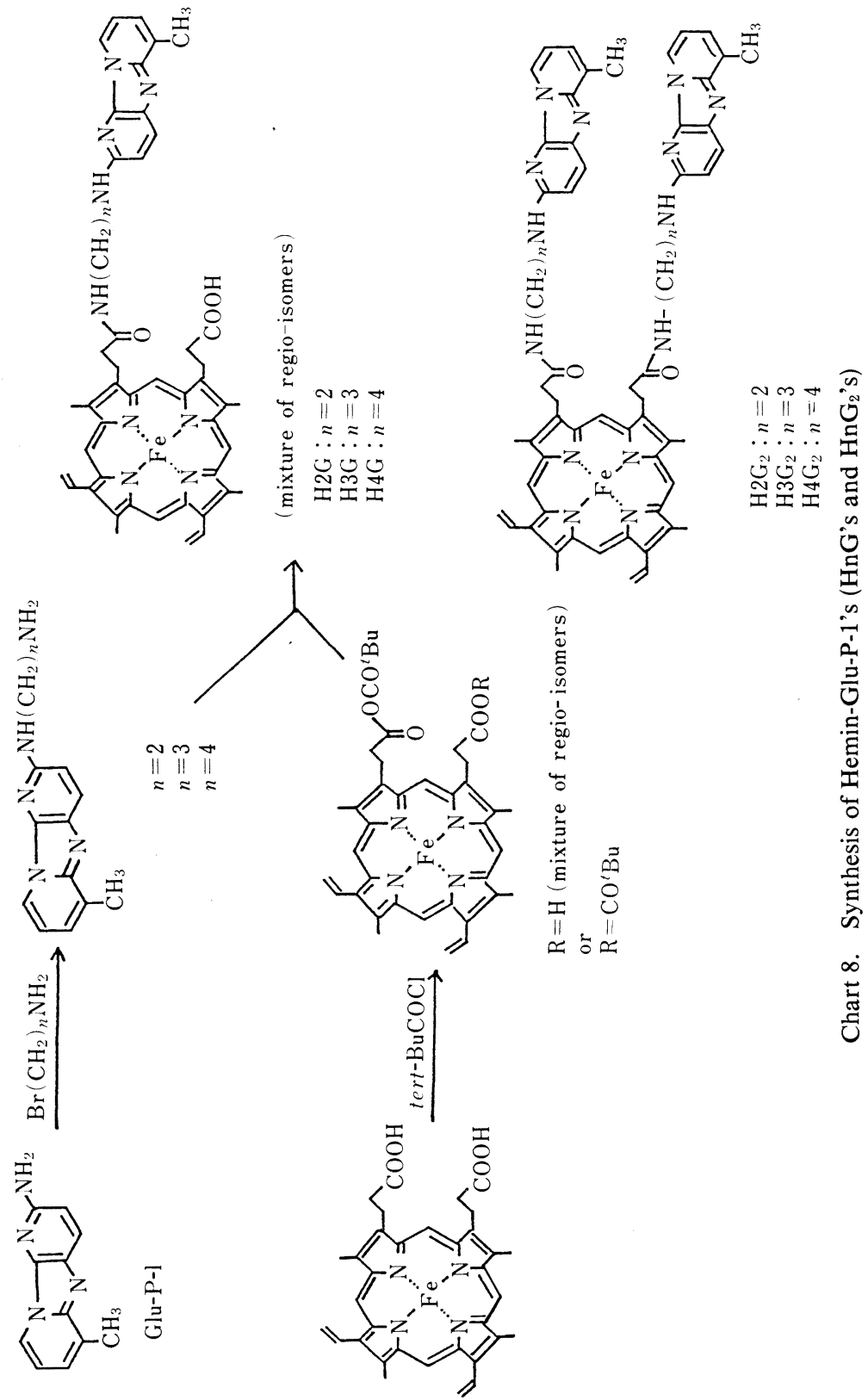

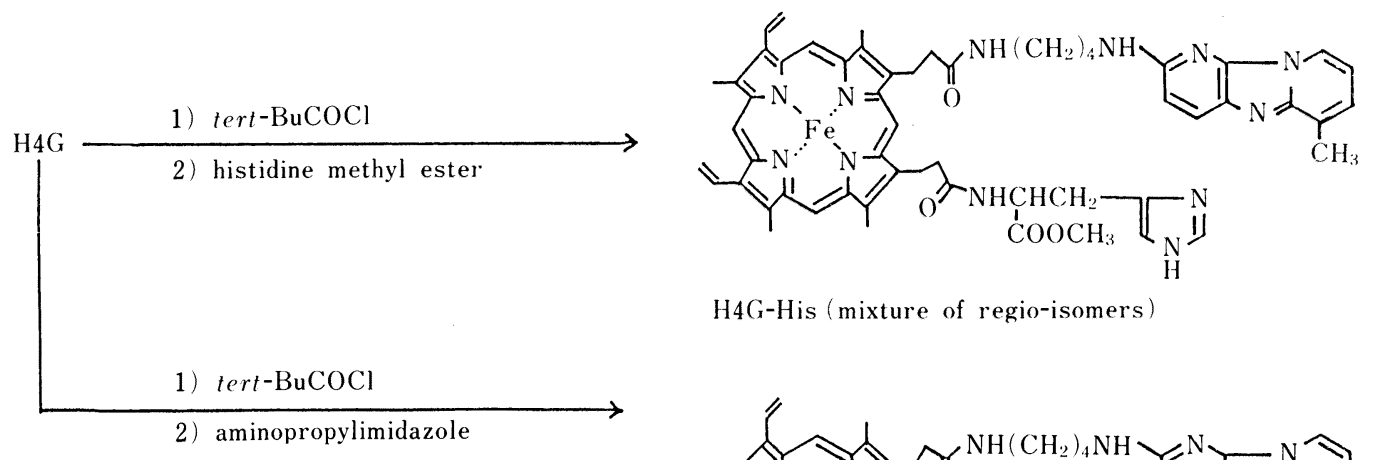

H4G-His (mixture of regio-isomers)

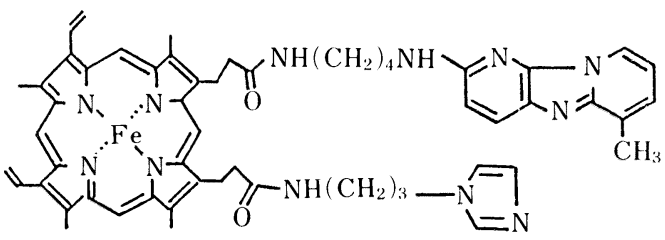

H4G-Im (mixture of regio-isomers)

Chart 9. Synthesis of Hemin-Glu-P-1's (H4G-His and H4G-Im)

TABle V. Percentage of Closed Circular DNA Which Was Converted to Open Circular DNA

\begin{tabular}{|c|c|c|c|c|c|c|c|c|}
\hline Drug & $\mu \mathrm{M}$ & $\%^{a)}$ & Drug & $\mu \mathrm{M}$ & $\%^{a)}$ & Drug & $\mu \mathrm{M}$ & $\%^{a)}$ \\
\hline None & & 9 & $\mathrm{H} 4 \mathrm{G}$ & 10 & 15 & H4G-Im & 10 & 47 \\
\hline $\mathrm{FeCl}_{2}$ & 100 & 8 & $\mathrm{H} 4 \mathrm{G}$ & 25 & 24 & H4G-Im & 25 & 46 \\
\hline Hemin & 100 & 10 & $\mathrm{H} 4 \mathrm{G}$ & 50 & 47 & H4G-Im & 50 & 50 \\
\hline $\mathrm{H} 2 \mathrm{G}_{2}$ & 100 & 39 & H4G & 100 & 42 & H4G-Im & 100 & 56 \\
\hline $\mathrm{H} 2 \mathrm{G}$ & 100 & 41 & $\mathrm{H} 4 \mathrm{G}+$ histidine $^{b)}$ & 100 & 41 & Bleomycin & 10 & 64 \\
\hline $\mathrm{H} 3 \mathrm{G}_{2}$ & 100 & 40 & $\mathrm{H} 4 \mathrm{G}+$ imidazole $^{b)}$ & 100 & 43 & Bleomycin & 50 & 78 \\
\hline $\mathrm{H} 3 \mathrm{G}$ & 100 & 40 & H4G-His & 10 & 36 & & & \\
\hline $\mathrm{H}_{4} \mathrm{G}_{2}$ & 10 & 20 & H4G-His & 25 & 50 & & & \\
\hline \multirow[t]{2}{*}{$\mathbf{H} 4 \mathbf{G}_{2}$} & 100 & 41 & $\mathrm{H} 4 \mathrm{G}-\mathrm{His}$ & 50 & 49 & & & \\
\hline & & & $\mathrm{H} 4 \mathrm{G}-\mathrm{His}$ & 100 & 64 & & & \\
\hline
\end{tabular}

The reaction mixture $(10 \mu \mathrm{l})$ contained final concentrations of $200 \mu \mathrm{M}$ nucleotides of pBR322 DNA, $4 \mathrm{~mm} \mathrm{Na}_{2} \mathrm{~S}_{2} \mathrm{O}_{4}, 10 \mathrm{~mm}$ Tris (pH 7.8), and $50 \mathrm{~mm} \mathrm{NaCl}$. The reaction mixture was saturated with air and incubated at $20^{\circ} \mathrm{C}$ for $1 \mathrm{~h}$.

a) The percentage was calculated from the ratio of closed circular DNA to open circular DNA. b) Concentration of the additive (histidine or imidazole) was $1 \mathrm{~mm}$.

これらのへミン-Glu-P-1 誘導体はまず Glu-P-1 部分で DNA Kインターカレートし，次いでへミン鉄部分に よる溶存酸素の還元活性化が DNA の近傍で生ずるために効率よくDNA 鎖が切断されると考えている.

IV-3. DNA 鎖切断の塩基配列選択性 前項で, 合成したへミシ-Glu-P-1 誘導体が高いDNA 鎖切断能を 有することを述べた。 へミン-Glu-P-1 唀導体によるDNA の切断位置を塩基配列のレベルで知るために, 末端を ${ }^{32} \mathrm{P}$ で放射標識した DNA を反応基質として DNA 鎖切断反応を行い, 生ずる DNA 断片を塩基配列決定用ゲ 儿電気泳動で分析した. 結果を Fig. 4 亿示す. ${ }^{52,53)}$ 星印の数が切断頻度を示している. 合成したへミン-Glu-P-1 誘導体はいずれもブレオマイシンとほぼ同一の塩基配列選択性をもって DNA 鎖を切断する.切断頻度は圧倒的 にグアニンーピリミジン塩基配列部分に高いことが分かった.

IV-4. DNA 切断断片の構造 ヘミン-Glu-P-1 誘導体もブレオマイシンも酸素依存的に DNA 鎖をグアニ ンーピリミジン塩基配列選択的に切断するが，その反応機構は DNA 鎖切断に係わる活性酸素種の特定もできて おらず不明である.筆者らはまず，これらの DNA 鎖切断試薬により切断された DNA 断片の切断部分 (末端) の構造を酵素化学的手法と塩基配列決定用ゲル電気泳動を併用して解析した。繁雑になるのでここでは得られた 


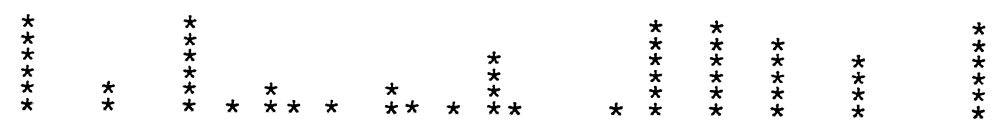

TTCTCATGTTTGACAGCTTATCATCGATAAGCTTTAATGCGGTAGTTTATCACAGTTAAA AAGAGTACAAACTGTCGAATAGTAGCTATTCGAAATTACGCCATCAAATAGTGTCAATTT $\stackrel{\star}{\star} \stackrel{\star}{*}$

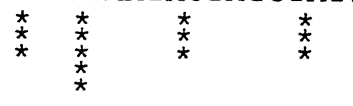

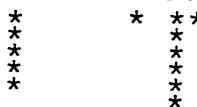

TTGCTAACGCAGTCAGGCACCGTGTATGAAATCTAACAATGCGCTCATCGTCATCCTCGGC AACGATTGCGTCAGTCCGTGGCACATACTTTAGATTGTTACGCGAGTAGCAGTAGGAGCCG

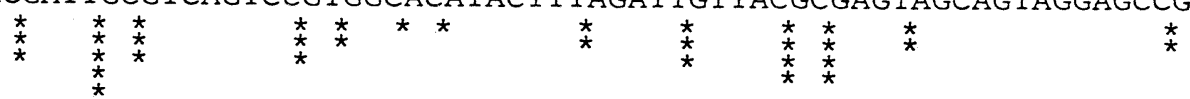

Fig. 4. Base-Sequence-Selective DNA Cleavage by Hemin-Glu-P-1's and by Bleomycin $*=$ relative probability of cleavage by Hemin-Glu-P-1's and by bleomycin.

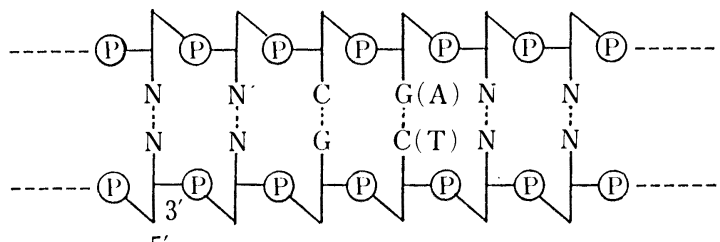

two nucleotide units deletion
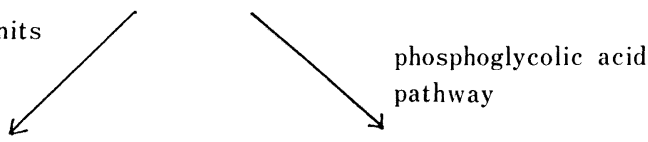

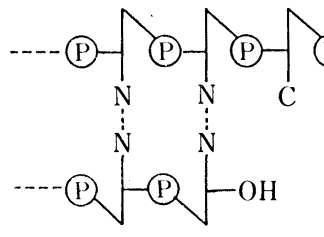

[B] $\mathrm{P}=-\frac{\mathrm{O}-\mathrm{P}_{1}^{1}}{\mathrm{O}}-\mathrm{O}-$

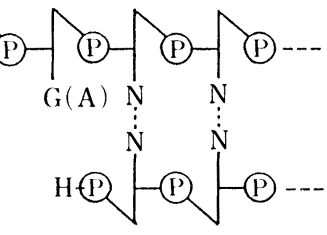

[A]

Chart 10. DNA Cleavage by Hemin-Glu-P-1's and by Bleomycin

結果の要点のみを述べる。詳細は文献 ${ }^{13,52,54)}$ を参照されたい。

(i) 切断された DNA の $3^{\prime}$ 側断片はピリミジン塩基の除去による DNA 鎖切断に対応する.

(ii) そしてその $3^{\prime}$ 側断片はアルカリ性ホスファターゼの基質となり，5' 末端にリン酸モノェステル構造を有 することが分かる.

(i) 及び (ii) から，切断された DNA の $3^{\prime}$ 側断片は Chart 10 の [A] で示される.

(iii) 次に, 切断された DNA の $5^{\prime}$ 側断片は少なくとも 3 種以上存在する. 
(iv) そしてそのらちの 1 つはターミナルデオキシヌクレオチジルトランスフェラーゼの基質となり， $3^{\prime}$ 末端 の構造が水酸基であることが分かる.

(v) この $5^{\prime}$ 側断片はグアニンの除去による DNA 鎖切断に引き続く $3^{\prime}$ 末端りン酸基の除去に対応している.

(iii)一(v) から, 切断された DNA の $5^{\prime}$ 側断片の 1 つは Chart 10 の [B] で示される. 他の $5^{\prime}$ 側断片の 1 つは 従来言われていた 3' 末端にホスホグリュール酸を有するもの吕である可能性が強く，この場合にはピリミジン 塩基の除去による DNA 鎖切断に対応する (Chart 10 の [C]).

ここに得られた結果はへミン-Glu-P-1 誘導体及びブレオマイシンに共通したものであり，現在までのところ， ヘミン-Glu-P-1 誘導体とブレオマイシンは同一の機構で DNA 鎖を切断すると考えている.

IV-5. 生物活性 以上, 合成したへミン-Glu-P-1 誘導体は DNA 鎖切断の塩基配列選択性においても, 生 ずる DNA の切断断片の構造においてもブレオマイシンと区別できない「ブレオマイシンの機能的アナログ!で あることを述べてきた．こらした点からもへミン-Glu-P-1 誘導体の生理活性に與味が持たれるが，国立がんセン ター研究所 佐々木环磨博士らによりハミン-Glu-P-1 誘導体の制癌試験がなされた. その結果一ミン-Glu-P-1 誘 導体のいくつかはエーリッヒ腹水癌担癌マウスの延命効果検定など数種の検定系に拈いてブレオマイシンと同様 の効果を示すことが明らかとなった. ${ }^{55)}$

本研究の成果は, ここに述べてきた分子設計の方法が新しい制癌剂開発のアプローチの1つになり得ることを 示したものと考えている.

\section{V. おわりに}

本総説の前半では数年前にグルタミン酸熱分解物中より単離された発癌性化合物, Glu-P-1, による化学発癌の 初期過程について述べた．その中で, Glu-P-1 による DNA の化学修飾過程については代謝活性体や修飾核酸塩 基の別途合成などを通じて化学的に確立したものであり, 生体内でも同様の DNA 化学修飾が生じていることを 証明した. 更に上述した DNA の Glu-P-1 による化学修飾が proto-ras の活性化の直接の原因であることを証明 することにより DNA 化学修飾と化学発癌の関連を明確にし, 最新の発癌機構研究の整合性に対して確たる基盤 を与えることができたものと考えている．腫瘍遺伝子産物の役割やその作用機作，発癌プロモーターの作用機作 などが今後早急に解決されねばならない研究課題であろら.

更に本総説後半では上記発癌性化合物, Glu-P-1 のインターカレーションによる DNA 認識能に着目した制癌 剂の分子設計について述べた。筆者らは化合物のインターカレート能と DNA 切断能という2つの測面のみから 考察を加えたがそれでもへミン-Glu-P-1 誘導体という目的とする活性を有する全く人工的な化合物を創製する ことができた．今後更に化合物の膜透過性や組織親和性などの薬物動力学的観点から，あるいは溶解性などの製 剤学的観点, 代謝化学的観点など, より総合的な広い, そして緻密な考察により更に優れた制癌剤の分子設計が 可能であると考えている.

謝辞本研究は東京大学薬学部名誉教授 岡本敏彦先生並びに東京大学薬学部教授 首藤紘一先生の御指導 のもとに行われたものであり，心から感謝致します．また本研究を行らに当り種々御指導頂きました国立がんセ ンター 杉村 隆総長, 静岡薬科大学 小菅卓夫教授, 国立がんセンター研究所 関谷剛男博士, の各先生に深 謝致します，更に共同研究者，太田敏晴，武田 敬，山口健太郎，李 金星，河内恵美了，今村正純，室伏良信， 飯島博之, 野崎義人, の諸氏に謝意を表します.

\section{引用 文 献}

1) T. Sugimura, S. Sato, Cancer Res., 43, 2415s (1983).

2) 橋本祐一, 首藤紘一, 岡本敏彦, ファルマシァ, 17, 326 (1981).

3）高山昭三, 大垣比呂子, 佐藤茂秋, 環境变異原研究, 7, 27 (1985).

4) 橋本祐一, 首藤紘一, 岡本敏彦, 化学の領域, 35, 25 (1981).

5) 橋本祐一, 首藤紘一, 衛生化学, 31, 298 (1985).

6) Y. Hashimoto, K. Shudo, Environ. Health Perspect., 62, 209 (1985).

7) 首藤紘一, 橋本祐一, 岡本敏彦, “動的天然物化学,” 後藤俊夫編, 講談社サイエンティフィック, 東京, 1983, p. 165.

8) Y. Hashimoto, K. Shudo, T. Okamoto, Acc. Chem. Res., 17, 403 (1984). 
9) Y. Hashimoto, K. Shudo, Environ. Health Perspect., 62, 219 (1985).

10) Y. Hashimoto, K. Shudo, T. Okamoto, Chem. Pharm. Bull., 28, 1961 (1980).

11) Y. Hashimoto, K. Shudo, T. Okamoto, Chem. Pharm. Bull., 31, 861 (1983).

12) Y. Hashimoto, K. Shudo, T. Okamoto, Tetrahedron Lett., 23, 677 (1982).

13) 橋本祐一, 首藤紘一, 有機合成化学, 43, 908 (1985).

14）橋本祐一, “生理活性物質の分子設計,”吉岡宏輔, 首藤紘一編, ソフトサイエンス社, 東京, 1986, p. 96.

15）小菅卓夫, 辻 邦郎, “化学の領域増刊, 128, 天然物化学 $80 \mathrm{~A}$,”南江堂, 東京, 1980, p. 71.

16) T. Yamamoto, K. Tsuji, T. Kosuge, T. Okamoto, K. Shudo, K. Takeda, Y. Iitaka, K. Yamaguchi, Y. Seino, T. Yahagi, T. Sugimura, Proc. Jpn. Acad., 54(B), 248 (1978).

17) K. Takeda, K. Shudo, T. Okamoto, T. Kosuge, Chem. Pharm. Bull., 26, 2924 (1978).

18) Y. Hashimoto, K. Shudo, T. Okamoto, Chem. Pharm. Bull., 27, 2532 (1979).

19) Y. Hashimoto, K. Shudo, T. Okamoto, J. Am. Chem. Soc., 104, 7636 (1982).

20) N. J. M. Birdsall, J. C. Parham, U. Wölke, G. B. Brown, Tetrahedron, 28, 3 (1972).

21）橋本祐一, 首藤紘一, “生化学実験講座・続, 第 1 巻, 遺伝子研究法 (I),”日本生化学会編, 東京化学同人, 東京, 1986 , p. 277.

22) Y. Hashimoto, K. Shudo, T. Okamoto, Chem. Pharm. Bull., 27, 1058 (1979).

23) Y. Hashimoto, K. Shudo, T. Okamoto, Chem. Pharm. Bull., 32, 4300 (1984).

24) Y. Murofushi, Y. Hashimoto, K. Shudo, T. Okamoto, Chem. Pharm. Bull., 29, 2730 (1981).

25) Y. Hashimoto, K. Shudo, Gann, 76, 253 (1985).

26) 首藤紘一, 薬誌, 102, 111 (1982).

27) Y. Hashimoto, K. Shudo, T. Okamoto, Biochem. Biophys. Res. Commun., 92, 971 (1980).

28) Y. Hashimoto, K. Shudo, T. Okamoto, Biochem. Biophys. Res. Commun., 96, 355 (1980).

29) T. Okamoto, K. Shudo, Y. Hashimoto, T. Kosuge, T. Sugimura, S. Nishimura, Chem. Pharm. Bull., 29, 590 (1981).

30) A. Shinohara, K. Saito, Y. Yamazoe, T. Kamataki, R. Kato, Carcinogenesis, 6, 305 (1985).

31) Y. Hashimoto, K. Shudo, T. Okamoto, Mutation Res., 105, 9 (1982).

32）山口健太郎, 板井昭子, 未発表.

33）今村正純, 未発表.

34) M. Imamura, K. Shudo, T. Okamoto, T. Andoh, Biochem. Biophys. Res. Commun., 97,968 (1980).

35) M. Imamura, K. Takeda, K. Shudo, T. Okamoto, C. Nagata, M. Kodama, Biochem. Biophys. Res. Commun., 96, 611 (1980).

36) A. M. Maxam, W. Gilbert, Methods Enzymol., 65, 499 (1980).

37) Y. Hashimoto, K. Shudo, Biochem. Biophys. Res. Commun., 116, 1100 (1983).

38) Y. Hashimoto, K. Shudo, Environ. Health Perspect., 62, 215 (1985).

39）高野利也, “発癌遺伝子,”講談社サイエンティフィック, 東京, 1984, p. 82.

40) T. Sekiya, M. Fushimi, H. Hori, S. Hirohashi, S. Nishimura, T. Sugimura, Proc. Natl. Acad. Sci., 81, 4771 (1984).

41）橋本鿆一, 日本薬学会第 106 年会講演要旨集, 一葉, 1986, p. 64.

42) Y. Hashimoto, E. Kawachi, K. Shudo, T. Sekiya, Nucleic Acids Res. Symp. Ser., in press.

43) T. Sekiya, V. S. Prassolov, M. Fushimi, S. Nishimura, Gann, 76, 851 (1985).

44) C.-S. Lee, Y. Hashimoto, K. Shudo, M. Nagao, Heterocycles, 22, 2249 (1984).

45) C.-S. Lee, Y. Hashimoto, T. Ohta, K. Shudo, T. Okamoto, Chem. Pharm. Bull., 30, 3046 (1982).

46) H. Tabor, Biochemistry, 1, 496 (1962).

47) M. Itoh, H. Kurokawa, M. Usui, M. Ohno, E. Shimoda, Y. Hashimoto, K. Shudo, Biochemistry, 24, 6401 (1985).

48）花岡文雄ら, 未発表.

49）長尾美奈子ら, 未発表.

50) L. F. Povirk, "Molecular Aspects of Anti-Cancer Drug Action," ed. by S. Neidle, M. J. Waring, Macmillan Press Ltd., London 1983, p. 157. 
51) Y. Hashimoto, C.-S. Lee, K. Shudo, T. Okamoto, Tetrahedron Lett., 24, 1523 (1983).

52) Y. Hashimoto, H. Iijima, Y. Nozaki, K. Shudo, Biochemistry, in press.

53) Y. Hashimoto, H. Iijima, K. Shudo, Gann, 75, 567 (1984).

54) Y. Hashimoto, H. Iijima, Y. Nozaki, K. Shudo, Nucleic Acids Res. Symp. Ser., 16, 193 (1985).

55）佐々木环磨ら, 未発表. 